\title{
NOTES ABOUT SPELLING AND CURRENCY
}

In this manuscript the names of vessels and periodicals are spelled as they appeared at the time. Thus, $A$ Classe Operaria is given no accent.

In the footnotes and the bibliographical list, authors' names and the titles of articles and books are spelled as they appeared on the actual copies of the works cited. Furthermore, efforts were made to keep name spelling in reference notes the same as that in the Sources of Material. This accounts for spelling in notes different from that in the text.

When expressed in figures, one mil-réis (one thousand réis) is written I\$000. One conto (one thousand mil-réis) is written I:000\$000. When expressed in figures, United States currency is indicated as follows: U.S. $\$ 1,000$. For conversion of mil-réis and contos to United States currency, see mil-réis entry in the glossary. 
THIS PAGE INTENTIONALLY LEFT BLANK 